\title{
STRATEGI BAURAN PEMASARAN UD. TROPICAL BATIK DUSUN KLONTANG DESA GENDOH KECAMATAN SEMPU KABUPATEN BANYUWANGI
}

\author{
Saifudin ${ }^{1}$, Sutrisno Djaja ${ }^{1}$, Hety Mustika Ani ${ }^{1}$ \\ ${ }^{1}$ Program Studi Pendidikan Ekonomi, Fakultas Keguruan dan Ilmu Pendidikan, Universitas Jember
}

\begin{abstract}
This study aims to review more deeply about marketing mix strategy used by UD. Tropical Batik in product marketing activities of the company. Determination of research location determined by Purposive Area method, that is done intentionally in UD. Tropical Batik Klontang Hamlet Gendoh Village Sempu Sub-district Banyuwangi Regency. The main informant in this study is the corporate managers and the supporting informants are company employees. Data collection methods used by researchers are interviews, observation, and documentation. Data analysis used in this research consists of several stages, they are data reduction, data presentation, and conclusion. The results showed that the product strategy used by UD. Tropical Batik is prioritice product quality by considering raw materials, production process, motif, and color. The pricing strategy used by determining the exact price in a accordance with the raw materials and production process. The strategies of promotion are exhibitions, cooperation with cooperatives and schools, and word-of-mouth promotion. Distribution strategies implemented are direct distribution to consumers and indirect distribution by cooperation with cooperatives and agents.
\end{abstract}

Keywords: Marketing Mix Strategy, UD. Tropical Batik

\section{PENDAHULUAN}

Saat ini perkembangan batik semakin meningkat, hal ini dapat dilihat dari meningkatnya permintaan produksi batik. Perkembangan perusahaan batik yang semakin banyak juga menjadi tantangan tersendiri bagi setiap perusahaan batik. Oleh sebab itu, dalam pengoperasian perusahaan juga harus mempertimbangkan strategi pemasaran agar mempunyai daya saing. Menurut (Wijayanti, 2014:13) Strategi marketing merupakan pedoman atau dasar pembuatan rencana marketing suatu produk dan taktik marketing. Strategi marketing ini juga digunakan sebagai pedoman untuk melakukan penjualan dan pendistribusian produk.

Strategi pemasaran merupakan hal penting bagi perusahaan, karena dalam memasarkan produk tentu menggunakan cara yang handal agar omzet penjualan mengalami peningkatan. Setiap perusahaan akan membuat strategi pemasaran dalam memasarkan produknya untuk menjaga dan memenuhi kebutuhan konsumen. Pemenuhan kebutuhan konsumen oleh perusahaan agar bisa sebaik mungkin untuk menyediakan produk batik yang mempunyai nilai lebih pada pandangan para konsumennya. Perusahaan juga harus mempunyai strategi pemasaran yang handal agar tujuan perusahaan dalam menarik minat konsumen tercapai.

Pada kabupaten dan kota di Indonesia sudah banyak beroperasi perusahaan batik yang membuat produk batik sesuai dengan corak masing-masing daerahnya. Sekian banyak perusahaan batik di Indonesia khususnya di pulau Jawa sudah banyak yang memasarkan produknya baik dalam negeri maupun luar negeri. Salah satunya adalah UD. Tropical Batik yang terletak di desa Gendoh, kecamatan Sempu, kabupaten Banyuwangi. Perusahaan ini memasarkan produknya di dalam negeri dan mengekspor produknya ke luar negeri.

Perusahaan yang berada di desa tentu secara faktor konsumen yang ingin membeli produk, maupun pendistribusian produk akan sedikit mengalami kesulitan. Secara letak 
geografis perusahaan ini bukan berada di kawasan industi batik yang sudah terkenal seperti Pekalongan, Solo, Jogjakarta dsb. Keadaan tersebut merupakan fenomena unik karena perusahaan yang bukan berasal dari daerah sentra industri batik mampu mengekspor produknya hingga ke luar negeri. Permasalahannya tentu persaingan perusahaan yang memproduksi batik akan semakin kompleks, maka hal yang harus dilakukan perusahaan yaitu memiliki strategi pemasaran yang handal dan mempunyai daya saing. Strategi pemasaran yang digunakan perusahaan ialah strategi bauran pemasaran atau marketing mix. Bauran pemasaran yang digunakan oleh perusahaan dengan mengoptimalkan unsur produk, harga, promosi, dan distribusi agar dapat mencapai tujuan yang diinginkan. Menurut Wijayanti (2014:47) bauran pemasaran merupakan hasil kolaborasi empat unsur, yang terdiri atas produk, harga, promosi, dan distribusi. Setiap unsurnya mempunyai peran dan fungsi yang berbeda, tetapi, merupakan satu kesatuan yang tidak bisa terpisahkan satu sama lain. Oleh karena itulah bauran marketing harus dibuat secara menyeluruh dan terarah dengan baik sesuai dengan strategi marketing yang telah ditetapkan, yaitu sesuai dengan segmen, target, dan posisi.

Assauri (2007:198) juga menyatakan bahwa marketing mix merupakan kombinasi variabel atau kegiatan yang merupakan inti dari sistem pemasaran, variabel yang dapat dikendalikan oleh perusahaan untuk mempengaruhi reaksi para pembeli atau konsumen. Fenomena ini mendorong peneliti untuk mengkaji lebih jauh strategi bauran pemasaran yang digunakan oleh perusahaan UD. Tropical Batik.

Berdasarkan uraian latar belakang diatas, maka perlu dirumuskan bagaimanakah strategi bauran pemasaran UD. Tropical Batik Dusun Klontang Desa Gendoh Kecamatan Sempu Kabupaten Banyuwangi.

\section{METODE PENELITIAN}

Penelitian ini dirancang dengan menggunakan pendekatan kualitatif yang berjenis penelitian deskriptif untuk membahas lebih dalam tentang strategi pemasaran yang digunakan oleh UD. Tropical Batik. Penentuan lokasi penelitian dengan menggunakan metode Purposive Area.

Sumber data dalam penelitian ini diperoleh dari informan utama dan informan pendukung. Informan utama dalam penelitian ini adalah manajer UD. Tropical Batik. Sedangkan informan pendukung dalam penelitian ini adalah dua karyawan UD. Tropical Batik meliputi karyawan ahli dan karyawan bagian produksi. Metode pengumpulan data yang digunakan oleh peneliti meliputi wawancara, observasi, dan dokumentasi. Analisis data yang digunakan oleh peneliti meliputi reduksi data, penyajian data, dan penarikan kesimpulan. Data yang terkumpul selanjutnya dilakukan pemeriksaan keabsaan data dengan menggunakan teknik Triangulasi.

\section{HASIL DAN PEMBAHASAN}

\section{Hasil Penelitian}

Penelitian ini bertujuan mengkaji strategi bauran pemasaran yang digunakan oleh UD. Tropical Batik. Perusahaan ini menggunakan strategi bauran pemasaran atau lebih dikenal dengan istilah Marketing Mix. Bauran pemasaran ini dengan memertimbangkan gabungan 
empat unsur, seperti produk, harga, promosi, dan distribusi. Adapun strategi yang digunakan oleh UD. Tropical Batik diantaranya sebagai berikut:

1. Produk: Produk yang dihasilkan UD. Tropical Batik dengan mengutamakan kualitas dari produk yang dihasilkan. UD. Tropical Batik selalu menjaga kualitas produknya dengan pemilihan bahan baku yang digunakan dan proses produksi dengan menggunakan tenaga kerja yang terampil dibidangnya. Perusahaan ini juga memproduksi batik dengan berbagai jenis dan produk lainnya yang berkualitas sehingga sampai sekarang masih diminati oleh para konsumen. Produk UD. Tropical Batik yang diproduksi juga mempertimbangkan pemilihan unsur motif dan warna yang menarik. Ciri khas yang ditawarkan perusahaan kepada konsumen yaitu dengan memadukan unsur klasik dan kontemporer pada batik khas Banyuwangi seperti pada motif batik gajah oling, motif jajang, motif kopi pecah, dan motif kangkung. Pemilihan kombinasi warna juga dilakukan oleh UD. Tropical Batik untuk membuat produk yang mempunyai ciri khas akan produk yang dihasilkan.

2. Harga: UD. Tropical Batik menetapkan harga produk dengan melihat penggunaan bahan baku yang digunakan dalam produksi, mengingat kain dan pewarna yang digunakan mempunyai kualitas yang berbeda. Kain yang digunakan oleh perusahaan meliputi kain sutera dan kain biasa yang mempunyai harga berbeda. Tingkat kesulitan produksi juga mempengaruhi harga produk, Karena batik yang mempunyai motif yang khas dan diharuskan memiliki ketelitian dalam produksinya. Waktu yang diperlukan untuk membuat batik juga menjadi salah satu faktor yang dipertimbangkan oleh perusahaan. UD. Tropical Batik dalam penentuan profit memperkirakan $20 \%$ dari harga jual produk. Penentuan profit yang ditentukan oleh perusahaan dapat berubah sesuai dengan jumlah barang yang dipesan oleh konsumen. Penentuan harga yang dilakukan UD. Tropical Batik diharapkan mampu menarik minat dan mempertahankan kepercayaan konsumen kepada perusahaan.

3. Promosi: Promosi yang dilakukan oleh UD. Tropical Batik yaitu dengan mengikuti pameran yang diadakan oleh pemerintah Kabupaten Banyuwangi dan bekerja sama dengan koperasi dalam penjualan produk. Promosi yang dilakukan oleh UD. Tropical Batik juga dengan membuka galeri batik untuk mengenalkan berbagai macam produk kepada konsumen. Perusahaan ini juga memberikan potongan harga terhadap konsumen yang memenuhi syarat tertentu. Pengenalan produk yang digunakan oleh UD. Tropical Batik yang mendasar adalah dengan cara dari mulut ke mulut yang terbukti efektif dalam meningkatkan penjualan produk batik di UD. Tropical Batik.

4. Distribusi: UD. Tropical Batik menggunakan sarana distribusi secara langsung dengan berkomunikasi mengenai produk kepada konsumen. Para konsumen pada umumnya datang sendiri ke galeri batik perusahaan untuk memesan produk batik secara langsung. Perusahaan juga menggunakan distribusi secara tidak langsung lewat perantara koperasi dan kerjasama dengan agen yang memasarkan produksi ke luar negeri. Diharapkan dari saluran distribusi tersebut perusahaan dapat memasarkan produk secara efektif.

\section{Pembahasan}

Berdasarkan hasil penelitian yang diperoleh dari UD. Tropical Batik menunjukkan bahwa strategi produk, harga, promosi, dan distribusi yang terkandung dalam strategi bauran pemasaran atau marketing mix. 
UD. Tropical Batik dalam memproduksi barang dengan tetap menjaga kualitas produk dan pemilihan motif batik. Perusahaan yang selalu menjaga kualitas produk dalam usahanya akan berdampak terhadap kepuasan dan kepercayaan konsumen terhadap perusahaan. Peningkatan terhadap produk yang dilakukan oleh UD. Tropical Batik dengan cara menambah variasi dan motif batik. Perusahaan juga memproduksi berbagai macam produk seperti batik printing, batik stamp, batik semi, batik tulis, seragam sekolah, seragam kantor, mukena, Hawaiian Dress, Sarung Pantai dan batik khas Banyuwangi yaitu batik gajah oling. Pemilihan kualitas bahan baku serta penambahan variasi dan motif produk yang dihasilkan oleh UD. Tropical Batik dilakukan agar menambah omzet penjualan perusahaan serta memenuhi kebutuhan dan keinginan konsumen. Fakta tersebut sesuai dengan pendapat yang dikemukakan oleh Wijayanti (2014:50) bahwa suatu produk yang diperjualbelikan dengan tujuan untuk mendapatkan keuntungan dari sesuatu hasil kreatifitas seseorang, tim marketing atau perusahaan. Produk atau jasa ini biasanya merupakan alat untuk memenuhi keinginan dan kebutuhan pelanggan serta bentuknya berwujud, dapat dilihat, dan menarik.

Penentuan harga yang diterapkan oleh UD. Tropical Batik kepada para konsumen mengacu pada kualitas produk. Kualitas suatu produk tergantung pada bahan baku dan kesulitan dalam proses produksinya. Bahan baku yang berbeda dan kesulitan pengerjaan produk juga mempengaruhi tingkat harga yang ditetapkan oleh perusahaan. Perusahaan berupaya dengan bahan baku yang mempunyai kualitas mampu memberikan harga yang dapat dijangkau oleh para konsumen, sehingga penetapan harga perusahaan dapat diterima konsumen. Fakta tersebut sesuai dengan pendapat yang dikemukakan oleh Tjiptono (1998:151) agar dapat sukses dalam memasarkan suatu barang atau jasa, setiap perusahaan harus menetapkan harganya secara tepat.

Pengenalan produk yang dilakukan perusahaan dalam hal ini meliputi promosi melalui pameran produk lokal, bekerjasama dengan koperasi, dan promosi dari mulut ke mulut. Kegiatan promosi ini diharapkan dapat menambah jumlah konsumen untuk dapat membeli produk yang dihasilkan. Fakta tersebut sesuai dengan pendapat Tandjung (2004:83) bahwa promosi dilakukan untuk berkomunikasi dan mempengaruhi calon konsumen agar dapat menerima produk-produk yang dihasilkan oleh perusahaan. Promosi pada hakikatnya seni untuk merayu pelanggan dan calon konsumen untuk membeli lebih banyak produk perusahaan.

Perusahaan juga melakukan penjualan produk secara langsung melalui galeri batik yang ada di perusahaan. Para konsumen yang datang ke galeri batik pada umumnya membeli produk dalam jumlah kecil. Pihak peerusahaan memang menyediakan beberapa produk yang dijadikan contoh batik sekaligus memproduksi stok barangnya dengan jumlah yang terbatas. Mengingat perusahaan mayoritas memproduksi pesanan batik dalam jumlah besar melalui pesanan dari konsumen. Fakta tersebut sesuai dengan penyataan Angipora (2002:299) juga menyatakan salah satu bentuk saluran distribusi yaitu saluran secara langsung atau Direct Channel yang tidak memanfaatkan atau melibatkan perantara-perantara independent.

Pendistribusian produk yang dilakukan perusahaan dengan menggunakan perantara atau pihak ketiga. Perusahaan sudah menjalin kerja sama dengan koperasi sebagai perantara untuk menyampaikan produk ke konsumen. UD. Tropical Batik juga bekerja sama dengan agen yang mengirim produk batik hingga ke luar negeri seperti Hawaii dan Las Vegas. Distribusi tidak langsung yang dilakukan perusahaan ini sesuai dengan pernyataan Yulisetiarini (2014:58) yang menyatakan saluran distribusi merupakan perantara-perantara (middlemen) para pembeli dan 
penjual yang dilalui oleh perpindahan barang baik phisik maupun perpindahan milik sejak dari produsen (producer, manufacturer) hingga ke tangan konsumen. Distribusi bisa dengan cara dari produsen kepada pengecer (retailer) kemudian kemudian baru ke konsumen atau dengan melalui distributor baru kemudian sampai ke konsumen.

\section{KESIMPULAN DAN SARAN}

\section{Kesimpulan}

Strategi pemasaran yang diterapkan perusahaan yaitu strategi bauran pemasaran. Strategi ini dengan memadukan unsur produk, harga, promosi, dan distribusi. Strategi produk perusahaan dengan mengutamakan kualitas produk dalam segi bahan baku, proses produksinya, dan motif dan warna produk batik. Strategi harga yang diterapkan perusahaan dengan cara menentukan harga yang tepat dengan mempertimbangkan bahan baku dan proses pembuatan produk. Strategi promosi yang dilakukan perusahaan dengan mengikuti pameran, potongan harga, kerjasama dengan koperasi dan sekolah sekitar, dan promosi dari mulut ke mulut. Strategi distribusi yang digunakan perusahaan dengan cara pengiriman langsung dan tidak langsung. Distribusi langsung perusahaan dengan menjalin komunikasi dan menjual langsung produk kepada konsumen. Sedangkan distribusi tidak langsung yang diterapkan oleh perusahaan meliputi menjalin kerja sama dengan koperasi dan agen yang menjual produk ke luar negeri.

\section{Saran}

Saran yang dapat diberikan dari penelitian ini kepada UD. Tropical Batik Dusun Klontang Desa Gendoh Kecamatan Sempu Kabupaten Banyuwangi adalah selalu meningkatkan produk yang dihasilkan dan menjaga kelestarian budaya Indonesia.

\section{DAFTAR BACAAN}

Angipora, Marius P. 2002. Dasar-Dasar Pemasaran. Jakarta. PT. Raja Grafindo Persada.

Assauri, Sofjan. 2007. Manajemen Pemasaran Dasar, Konsep, dan Strategi. Jakarta: Raja Grafindo Persada.

Tandjung, Jenu Widjaja. 2004. Marketing Manajemen Pendekatan pada Nilai-nilai Pelanggan. Malang. Bayumedia Publishing.

Tjiptono, Fandy. 1998. Strategi Pemasaran. Yogyakarta: ANDI

Wijayanti, Titik. 2014. Marketing Plan! Dalam Bisnis (Second Edition). Jakarta: PT Elex Media Komputindo.

Yulisetiarini, Diah. 2014. Intisari Marketing. Jember. Cahaya Ilmu. 